\title{
A Time Series Analysis of the Trend of Crime Against Property in Oke-Ogun Region of Oyo State, Nigeria
}

\author{
${ }^{* 1}$ IGE James Olateju and ${ }^{2}$ OKUNOLA Babajide Kehinde \\ ${ }^{1}$ Department of Urban and Regional Planning, Faculty of Environmental Sciences, Ladoke Akintola University of \\ Technology, Ogbomoso, Oyo State, Nigeria \\ ${ }^{2}$ Department of Geography, School of Secondary Education (Arts and Social Sciences Programs), Federal College of \\ Education (Special), Oyo, Oyo State, Nigeria
}

*Corresponding Author: joige@lautech.edu.ng Tel.: +2348066108567

Submitted on: $25 / 05 / 2021$

Accepted on: 06/09/2021

\begin{abstract}
Temporal variation in spatial crime occurrence has been a topical issue in environmental criminology and criminal justice research, especially in the area of generating early warning systems for preparedness against crime. However, the concentration of research effort on urban crime pattern with unjustified neglect of regional crime impedes the search for analytical explanations and effective strategies to eradicate crime. Hence, this study examined fluctuant pattern of property crime in OkeOgun region of Oyo State, Nigeria. It also assessed direction and incidence speed of the crime in the area. This is with a view to understanding the influence of changes in time (year factor) and other factors (a faulty system of education, erosion of traditional values, porous border, and unemployment among others). over property crime occurrence in the region. Crime reports were collated from the Nigerian Police records on nine typologies of property crime from 2005 to 2012. The geo-analytical techniques employed to examine temporal variations in crime were exponential trend smoothing technique with a smoothing constant of 0.3 and the least-squares trend analytical technique. Regression and correlation coefficients represented by " $b$ " and " $r$ " respectively were used to determine the changing rate of the crimes over the period of year under investigation. Analysis showed that out of the nine crime types that were analysed, three crimes were found to exhibit a rising trend with the effluxion of year while six exhibited a declining trend. Aggregately, crime against property had downward sloping trend lines. The negative values associated with $(b=-93.04, r=-$ 0.62) property crime confirmed the negative lapse rates and inverse relationships. The coefficient of determination $\left(r^{2}\right)$ in this case is 0.3969 . However, the study concluded that $39.69 \%$ of variations in the level of property crime were influenced by changes in year and $60.31 \%$ was explained by other factors which included a faulty system of education, erosion of traditional values, porous border, and unemployment among others.
\end{abstract}

Keywords: temporal variation, property crime, region, Oke-Ogun, Nigeria

\section{Introduction}

Generally, the overall public apprehension of security crisis and the attendant crime in Nigeria has to do with crime on property and persons. Needless to say, the dominant perception of insecurity in Nigeria today is that fears for personal and private safety and safety of property in particular arising from purely criminal activities such as armed or unarmed robbery, house and store breakings, just to mention a few. Crime, as Omisakin (1998) expresses, "is a social menace, an undeniable stigma to national image and a significant source of threat to people's safety and wellbeing".

Temporal variations in crime are a topical issue in criminological research, and they are among of the least understood topics in the field of environmental criminology and criminal justice, especially in the area of generating early warning systems for preparedness against crime. Over and over, attempts at understanding various aspects of crime have been carried out in different disciplines. Spatial and/or temporal dimension of crime are also obvious but often less considered in most of attempts at understanding various aspects of crime by non-geographers and other non-spatial planners and analysts. Such attempts are in the works of Adejumobi, et al (2009), Obudho and Owuor (1994); and Odekunle (1982). The attempts have almost always tried to establish, a clear link between mental life, 
modernization, socialisation and increasing level of criminality with little or no reference to temporal dimension to explain how crime vary with time in a particular area. Nevertheless, until recently, the literature on spatial criminology has almost exclusively focused on cities with little efforts on regional problems and the attempts on crime studies include the works of Aust and Simmons (2002), Jones (2003), Mawby (2006), Adeboyejo, and Abodunrin (2007), Okoko (2008), Ahmed (2010) and Adigun (2012). Hence, analysis of regional crime occurrence has been relatively neglected and so the literature on regional crime and justice is comparatively sparse. However, those attempts sometimes can conceal patterns of crime variations in some locations and it must be understood here that solutions to crime phenomena in an environment lie in understanding the spatial variation in crime trend and prevention for planning and management of security operations.

The regional concept holds that the surface of the earth can be marked off into spatial units or areal levels of distinctive character (Omuta and Onokerhoraye, 1986). Okafor (2004) holds that regions are portions of territory each of which is internally homogenous (or largely so) with regard to some attributes. In the context of regional planning, these attributes could be unemployment, agricultural output, industrial output, school environment, infant mortality just to mention a few. Regions are defined on the basis of some significant attributes. Thus, the component parts of a region usually have some similarity in terms of the attributes on the basis of which the region is defined. However, regions are not arbitrarily defined or demarcated areas. Regions are supra urban areas comprising rural and urban environments.

Theoretically, it has been argued that there exists a close and positive relationship between crime occurrence and ecological area in any space economy (Sampson, 1995; La Grange 1999). In same way, the extricable relationship between the physical attributes of Oke-Ogun area, and the prevalence of various types of crime incidence cannot be over-emphasized. Oke-Ogun region has geographical peculiarities with possible implication for incidence of crime prevalence Oke-Ogun region is porous and remains an open countryside. The strategic location of Oke-Ogun area as a transit point to the northern and south-western Nigeria and Republic of Benin makes it prone to criminality and a choice for the research. Locational crime studies on Oke-Ogun and some other borderlands in Nigeria are too few. However, the study examined pattern, direction and relative speed of crime against property in Oke-Ogun region of Oyo State in southwestern Nigeria. This is with a view to assessing the variations in the frequency of crime against property and determining the association between crime frequency and year in the region.

\section{Materials and Methods}

The study area is Oke-Ogun region in Oyo State. Oke-Ogun region is the north-western area of Oyo State, and is made up of ten local government areas in the northern and north-western parts of Oyo State, Nigeria. Geographically, Oke-Ogun approximately stretches between latitudes $07^{\circ} 28^{\prime}$ and $08^{\circ}$ $38^{\prime}$ North and longitudes $03^{\circ} 02^{\prime}$ and $04^{\circ} 44^{\prime}$ East (Figure 1.).

Oke-Ogun shares boundary with Kwara State in the North, in the South by Ogun State, Ibarapa North and Ibarapa East local government areas; in the East by Atiba and Oyo West local government areas, and in the West by Republic of Benin. Oke-Ogun area is a borderland consisting of ten local government areas. The ten LGAs are districted into three zones, namely;

(i) Border zone: This comprises Saki West, Atisbo and Iwajowa local government areas. The local government areas within this zone share boundary with the Republic of Benin

(ii) Near border zone: This comprises Saki East, Itesiwaju, Kajola and Iseyin local government areas. These local government areas share boundary with the local government areas sharing boundary with the Republic of Benin. This implies that they are indirectly connected to the border. 


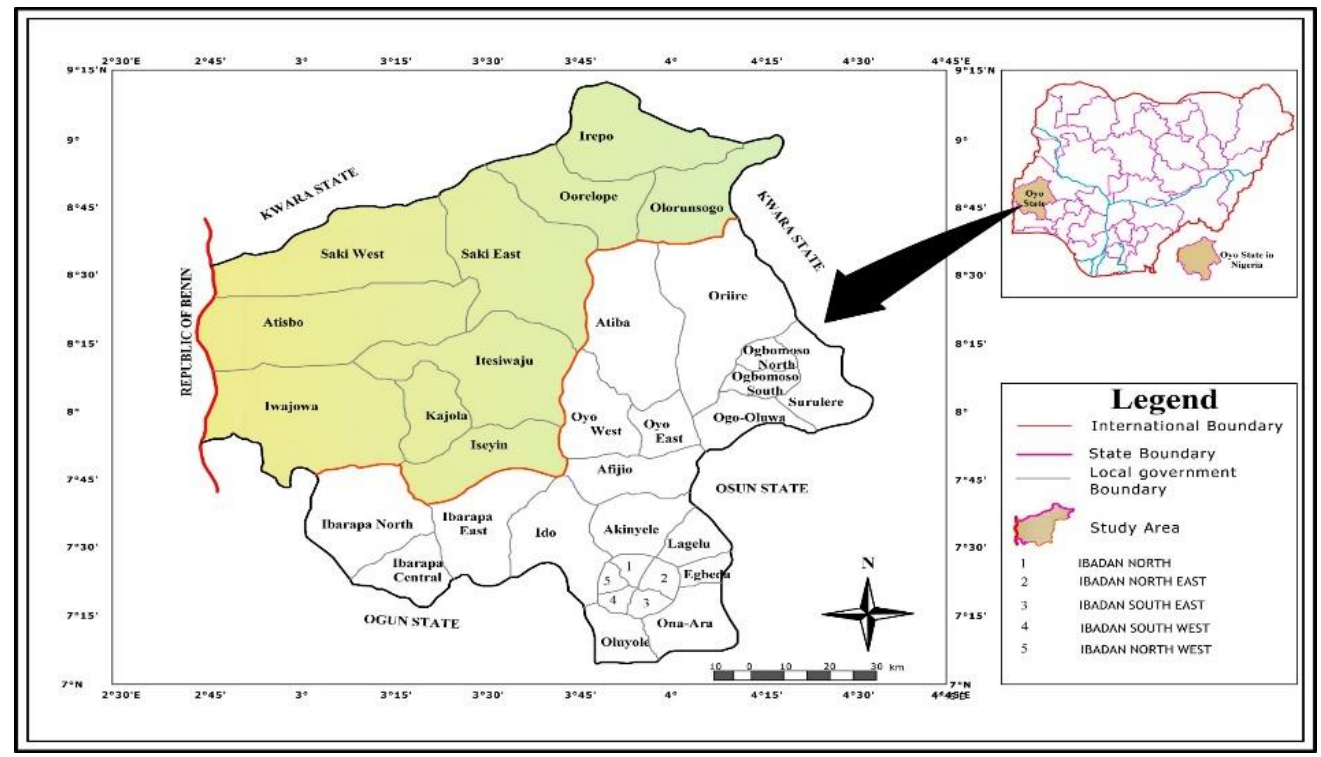

Figure 1: Oke-Ogun Region, Oyo State

(iii) Far border zone: It comprises Orelope, Olorunsogo and Irepo local government areas. These local government areas share boundary with Kwara State which shares boundary with the Republic of Benin. Also, these local government areas are indirectly connected to the border. The people of Oke-Ogun are mostly Yoruba. The regional accent of Oke-Ogun is called "Onko". Some ethnic groups like Ibaruba, Filani, Aketepe, and foreigners from Republic of Benin and Togo are found practising agriculture in the area.

Police records on crime against properties in the study area collected from Oyo State Police Headquarters were used. Temporal variation in nature of crime in Oke-Ogun region from 2005 to 2012 was examined using the exponential smoothing and least square techniques to present the spatial crime information in a graphical format for understanding the rampant trend of crime in the region. The mathematical characteristics of the exponential smoothing trend analysis is given as:

$$
\mathbf{T}_{\mathbf{n}}=\alpha(\varnothing)+(1-\alpha)(\beta)
$$

Where: $\mathbf{T}_{\mathbf{n}}=$ new trend or predicted trend value; $\boldsymbol{\alpha}=$ a smoothing constant; $\varnothing=$ actual value for current period; $\boldsymbol{\beta}=$ trend value for last period.

In this technique, the trend value for the first data is the same as the value for the first raw data. For subsequent data, the trend value was calculated using the formula. The commonly used smoothing constant ranges from 0.3 to 0.5 , and a smoothing constant of 0.3 was used in this study. The exponential smoothing technique was used to smoothen pattern of crime fluctuation (bring out the rising or falling trend of crime). The Least-Squares technique was used to explain pattern and rate of crime. It was used to obtain regression line that gave the clearest picture of the rising or falling pattern of crime, and determine the linear relationship between years under investigation and their crime incidence. The mathematical characteristics of the least-square techniques is given as:

$$
y=a+b x
$$

Where: $\mathrm{y}=$ predicted future crime incidence; $\mathrm{a}=$ slope intercept, the value of $\mathrm{y}$ when $\mathrm{x}=0$; $\mathrm{b}=$ regression coefficient, constant, representing the amount of change in $\mathrm{y}$ that corresponding to a change of one (1) unit in year $\mathrm{x}=$ year

For predictive purposes, mathematical models were generated from regression analysis. Regression coefficient (b) and Pearson's product-moment correlation coefficient (r) were employed to determine the speed (strength of the rate of decrease or increase) of crime with the efflux of time in the study 
area. The percentage contribution of $\mathrm{x}$ (period of year) to variation in $\mathrm{y}$ (level of crime occurrence) is determined using the coefficient of determination $\left(r^{2}\right) \cdot r^{2}$ in this case is got by simply squaring " $r$ " value then multiplied by 100 Therefore $r^{2}$ is $100 \times r^{2}$

\section{Results and Discussions \\ Temporal Variations in Crime against Property in Oke-Ogun}

Data on incidences of crime against property in Oke-Ogun from 2005-2012 were plotted as a timeseries data with a view to establishing the trend of crime against property cases over the years under study (Table 1). The exponential smoothing trend line was able to give the picture of a falling trend in Oke-Ogun. However, the rate of decline was swift (Fig.2). This was attested to by the low and negative values of the regression and correlation co-efficient $(r=-0.62)$, meaning that with time the frequency of crime against property decreased in the area and the relationship between level of crime occurrence with the efflux of time was very high and direct. The coefficient of determination $\left(\mathrm{r}^{2}\right)$ in this case is 0.3969 . Therefore $39.69 \%$ of variations in the level of property crime was influenced by time factor (changes in year). So, $60.31 \%$ was explained by other factors. The least squares model is given in this equation 5 .

$$
\mathrm{y}=1428.8-93.036 \mathrm{x}
$$

The model implies that a unit increase in year would bring about 93.036 units decrease in the case of crime against property in Oke-Ogun region.

Table 1: Trend Values for Crime against Property

\begin{tabular}{llll}
\hline Year & Empirical values & $\mathbf{T n}=\boldsymbol{\alpha}(\varnothing)+(\mathbf{1 - \alpha})(\boldsymbol{\beta})$ & $\mathbf{Y = a + b x}$ \\
\hline $\mathbf{2 0 0 5}$ & 1187 & 1187 & 1335.77 \\
$\mathbf{2 0 0 6}$ & 1138 & 1172.3 & 1242.74 \\
$\mathbf{2 0 0 7}$ & 1147 & 1164.71 & 1149.71 \\
$\mathbf{2 0 0 8}$ & 1719 & 1331 & 1056.68 \\
$\mathbf{2 0 0 9}$ & 665 & 1131.2 & 963.65 \\
$\mathbf{2 0 1 0}$ & 902 & 1062.44 & 870.62 \\
$\mathbf{2 0 1 1}$ & 644 & 936.91 & 777.59 \\
$\mathbf{2 0 1 2}$ & 679 & 589.54 & 684.56 \\
\hline
\end{tabular}

Source: Field Research, 2014

\section{The Trend of Individual Property Crime \\ Armed Robbery}

The rate of decrease of armed robbery cases in the number of years as examined by exponential smoothing and the least-square techniques is given in Table (2). However, the relationship between the frequency of armed robbery and the effluxion of years was strong though indirect. This is attested to by the high and negative values of the regression and correlation coefficients $(b=-1.5952)$ and $(r=-$ $0.73)$ respectively. The implication is that the trend of armed robbery was decreasing at a very rapid speed. The regression model in equation (.4):

$$
y=34.429-1.5952 x
$$

The model implies that a unit increase in year would bring about 1.5952 units decrease in the case of armed robbery in Oke-Ogun region. 
LAUTECH Journal of Civil and Environmental Studies

Volume 7, Issue 2; September 2021

Table 2: Empirical and Predicted Frequencies of the Trend of Armed Robbery

\begin{tabular}{llll}
\hline Year & Empirical values & $\mathbf{T n}=\boldsymbol{\alpha}(\varnothing)+(\mathbf{1 - \alpha})(\boldsymbol{\beta})$ & $\mathbf{Y}=\mathbf{a}+\mathbf{b x}$ \\
\hline $\mathbf{2 0 0 5}$ & 39 & 39.00 & 32.83 \\
$\mathbf{2 0 0 6}$ & 27 & 35.40 & 31.24 \\
$\mathbf{2 0 0 7}$ & 28 & 33.18 & 29.64 \\
$\mathbf{2 0 0 8}$ & 27 & 31.33 & 28.05 \\
$\mathbf{2 0 0 9}$ & 25 & 29.43 & 26.45 \\
$\mathbf{2 0 1 0}$ & 26 & 28.40 & 24.86 \\
$\mathbf{2 0 1 1}$ & 20 & 25.88 & 23.26 \\
$\mathbf{2 0 1 2}$ & 26 & 25.92 & 21.67 \\
\hline
\end{tabular}

Source: Field Research, 2014

\section{Burglary}

Info-graphic trend of burglary cases in Oke-Ogun was observed to be moving upward (Table 3). This is attested to by the low and positive values of the regression and correlation coefficients $(b=$ $+1.5357)$ and $(\mathrm{r}=+0.03)$ respectively. The implication is that the trend of burglary in Oke-Ogun increased at a very slow speed as the years increased and there was a low positive association between crime occurrence and year. The regression model in equation (5) corroborates this.

$$
y=253.21+1.5357 x
$$

The model implies that a unit increase in year would bring about 1.5357 unit increase in the case of burglary in Oke-Ogun region.

Table 3: Trend Values for Burglary

\begin{tabular}{llll}
\hline Year & Empirical values & $\operatorname{Tn}=\alpha(\varnothing)+(1-\alpha)(\beta)$ & $\mathrm{Y}=\mathrm{a}+\mathrm{bx}$ \\
\hline $\mathbf{2 0 0 5}$ & 174 & 174.00 & 254.75 \\
$\mathbf{2 0 0 6}$ & 211 & 185.10 & 256.28 \\
$\mathbf{2 0 0 7}$ & 252 & 205.17 & 257.82 \\
$\mathbf{2 0 0 8}$ & 585 & 319.12 & 259.35 \\
$\mathbf{2 0 0 9}$ & 88 & 249.78 & 260.89 \\
$\mathbf{2 0 1 0}$ & 374 & 287.05 & 262.42 \\
$\mathbf{2 0 1 1}$ & 123 & 237.84 & 263.96 \\
$\mathbf{2 0 1 2}$ & 274 & 245.69 & 265.39 \\
\hline
\end{tabular}

Source: Field Research, 2014

\section{Theft and Stealing}

The empirical data, when plotted on a coordinate axis, showed a fluctuation of the cases, but the negative values associated with the regression and correlation coefficients respectively $(b=-70.11)$ and $(r=-79)$ tespectively confirm the negative lapse rate and an inverse relationship. However, the speed of decline. $(b=-70.12)$ was swift as the year increased.

$$
\mathrm{y}=677.35-70.107 x
$$

The model implies that a unit increase in year would bring about 70.107 units decrease in the case of theft and stealing in Oke-Ogun region. 
Table 4: Trend Values for Theft and Stealing

\begin{tabular}{llll}
\hline Year & Empirical values & $\mathbf{T n}=\boldsymbol{\alpha}(\varnothing)+(\mathbf{1 - \alpha})(\boldsymbol{\beta})$ & $\mathbf{Y = a}+\mathbf{b x}$ \\
\hline $\mathbf{2 0 0 5}$ & 465 & 465 & 607.24 \\
$\mathbf{2 0 0 6}$ & 630 & 514.50 & 537.14 \\
$\mathbf{2 0 0 7}$ & 566 & 529.95 & 467.03 \\
$\mathbf{2 0 0 8}$ & 567 & 541.07 & 396.92 \\
$\mathbf{2 0 0 9}$ & 139 & 420.45 & 326.82 \\
$\mathbf{2 0 1 0}$ & 131 & 333.62 & 256.71 \\
$\mathbf{2 0 1 1}$ & 265 & 313.03 & 186.60 \\
$\mathbf{2 0 1 2}$ & 132 & 258.72 & 116.49 \\
\hline
\end{tabular}

Source: Field Research, 2014

\section{House Breaking}

There was observed a fluctuation of the cases (Table 5). However, the regression technique was far more explicit in depicting the rising trends of house-breaking cases in Oke-Ogun. This increasing trend, though very slow was confirmed by a weak positive correlation coefficient value $(r=+0.22)$ and the regression coefficient $(b=+3.3)$

$$
y=157.5+3.33 x
$$

The model implies that a unit increase in year would bring about 3.33 units increase in the case of house breaking in Oke-Ogun region

Table 5: Trend Values for House Breaking

\begin{tabular}{llll}
\hline Year & Empirical values & $\mathbf{T n}=\boldsymbol{\alpha}(\varnothing)+(\mathbf{1 - \alpha})(\boldsymbol{\beta})$ & $\mathbf{Y}=\mathbf{a}+\mathbf{b x}$ \\
\hline $\mathbf{2 0 0 5}$ & 181 & 181 & 160.83 \\
$\mathbf{2 0 0 6}$ & 122 & 163.3 & 164.16 \\
$\mathbf{2 0 0 7}$ & 103 & 145.21 & 167.49 \\
$\mathbf{2 0 0 8}$ & 215 & 166.15 & 170.82 \\
$\mathbf{2 0 0 9}$ & 116 & 151.11 & 174.15 \\
$\mathbf{2 0 1 0}$ & 145 & 149.28 & 177.48 \\
$\mathbf{2 0 1 1}$ & 118 & 139.89 & 180.81 \\
$\mathbf{2 0 1 2}$ & 140 & 139.92 & 184.14 \\
\hline
\end{tabular}

Source: Field Research, 2014

\section{Store Breaking}

The analysis established downward slope of the trend lines (Table 6). The negative values associated with both the regression and correlation coefficient $(r=-0.71)$ was very strong and therefore confirm the negative lapse rate and an inverse relationship, Store Breaking is rapidly declining as the years go by.

$$
\mathrm{y}=121.43-11.762 \mathrm{x}
$$

The model implies that a unit increase in year would bring about 11.762 decrease in the case of store breaking in Oke-Ogun region.

Table 6: Empirical and Predicted Trend of Store Breaking

\begin{tabular}{llll}
\hline Year & Empirical values & $\mathbf{T n}=\boldsymbol{\alpha}(\varnothing)+(\mathbf{1 - \alpha}) \mathbf{( \beta )}$ & $\mathbf{Y = a + b x}$ \\
\hline $\mathbf{2 0 0 5}$ & 87 & 87 & 109.67 \\
$\mathbf{2 0 0 6}$ & 85 & 86.40 & 79.91 \\
$\mathbf{2 0 0 7}$ & 85 & 85.98 & 86.14 \\
$\mathbf{2 0 0 8}$ & 105 & 91.69 & 74.38 \\
$\mathbf{2 0 0 9}$ & 117 & 99.28 & 62.62 \\
$\mathbf{2 0 1 0}$ & 46 & 83.29 & 50.86 \\
$\mathbf{2 0 1 1}$ & 05 & 59.80 & 39.10 \\
$\mathbf{2 0 1 2}$ & 18 & 47.26 & 27.33 \\
\hline
\end{tabular}

Source: Field Research, 2014 
LAUTECH Journal of Civil and Environmental Studies

Volume 7, Issue 2; September 2021

\section{Arson /Malicious Damage}

The trend of Arson / Malicious damage was characterised by crests and troughs and therefore not quite easy to discern Analysis established downward trend (Table 7). The rate of the decrease of the trend was slow judging by the low values of the regression and the correlation coefficients $(r=-0.40)$. Regression model generated is

$\mathrm{y}=19.75-0.75 \mathrm{x}$

The model implies that a unit increase in year would bring about a 0.75 unit decrease in the case of arson/malicious damage in Oke-Ogun region.

Table 7: Trend value for Arson

\begin{tabular}{llll}
\hline Year & Empirical values & $\mathbf{T n}=\boldsymbol{\alpha}(\boldsymbol{\varnothing})+(\mathbf{1}-\boldsymbol{\alpha})(\boldsymbol{\beta})$ & $\mathbf{Y}=\mathbf{a}+\mathbf{b x}$ \\
\hline $\mathbf{2 0 0 5}$ & 19 & 19.00 & 19.00 \\
$\mathbf{2 0 0 6}$ & 12 & 16.90 & 18.25 \\
$\mathbf{2 0 0 7}$ & 20 & 17.83 & 17.50 \\
$\mathbf{2 0 0 8}$ & 24 & 19.68 & 16.75 \\
$\mathbf{2 0 0 9}$ & 17 & 18.88 & 16.00 \\
$\mathbf{2 0 1 0}$ & 14 & 17.42 & 15.25 \\
$\mathbf{2 0 1 1}$ & 10 & 15.19 & 14.50 \\
$\mathbf{2 0 1 2}$ & 15 & 15.13 & 13.75 \\
\hline
\end{tabular}

Source: Field Research, 2014

\section{Forgery}

When the information in (Table 8) was plotted graphically the trend of forgery cases in Oke-Ogun area was declining very swift. This is attested to by the very low and negative values of the regression coefficient $(\mathrm{b}=-2.34)$ (equation 8) and the correlation coefficient $(\mathrm{r}=-0.90)$. The least-square model is;

$$
y=35.036-2.369 x
$$

The model implies that a unit increase in year would bring about 2.369 unit decrease in the case of forgery in Oke-Ogun region.

Table 8: Trend values for Forgery

\begin{tabular}{llll}
\hline Year & Empirical values & $\mathbf{T n}=\boldsymbol{\alpha}(\varnothing)+(\mathbf{1}-\boldsymbol{\alpha})(\boldsymbol{\beta})$ & $\mathbf{Y}=\mathbf{a}+\mathbf{b x}$ \\
\hline $\mathbf{2 0 0 5}$ & 31 & 31.00 & 32.67 \\
$\mathbf{2 0 0 6}$ & 32 & 31.30 & 30.29 \\
$\mathbf{2 0 0 7}$ & 29 & 30.61 & 27.93 \\
$\mathbf{2 0 0 8}$ & 22 & 28.03 & 25.56 \\
$\mathbf{2 0 0 9}$ & 28 & 28.02 & 23.19 \\
$\mathbf{2 0 1 0}$ & 18 & 25.01 & 20.82 \\
$\mathbf{2 0 1 1}$ & 20 & 23.51 & 18.45 \\
$\mathbf{2 0 1 2}$ & 15 & 20.96 & 16.08 \\
\hline
\end{tabular}

Source: Field Research, 2014

\section{False Pretence and Cheating}

Analysis established the frequency of false pretence and cheating as the year increased to have been decreasing in the area. (Table 9). However, the actual rate of decline was found to be strongly rapid as confirmed by the negative values associated with correlation coefficient $(r=-0.78)$ of the crime. The least-square model is;

$$
y=129.18-11.512 x
$$


The model implies that a unit increase in year would bring about 11.512 units decrease in the case of false pretence and cheating in Oke-Ogun region.

Table 9: Trend value for false pretence and cheating

\begin{tabular}{llll}
\hline Year & Empirical values & $\mathbf{T n}=\boldsymbol{\alpha}(\varnothing)+(\mathbf{1 - \alpha})(\boldsymbol{\beta})$ & $\mathbf{Y}=\mathbf{a}+\mathbf{b x}$ \\
\hline $\mathbf{2 0 0 5}$ & 150 & 150.00 & 117.67 \\
$\mathbf{2 0 0 6}$ & 105 & 136.50 & 106.16 \\
$\mathbf{2 0 0 7}$ & 51 & 110.85 & 94.64 \\
$\mathbf{2 0 0 8}$ & 92 & 105.19 & 83.13 \\
$\mathbf{2 0 0 9}$ & 54 & 89.83 & 71.62 \\
$\mathbf{2 0 1 0}$ & 67 & 82.98 & 60.11 \\
$\mathbf{2 0 1 1}$ & 51 & 73.39 & 48.60 \\
$\mathbf{2 0 1 2}$ & 49 & 66.07 & 37.08 \\
\hline
\end{tabular}

Source: Field Research, 2014

\section{Unlawful possession}

The direction of the trend of unlawful possession was not quite clear with the empirical and exponential smoothing values (Table 10). The rising pattern of the trend was vivid with least squares trend line. Judging by the very low coefficients of the regression and correlation $(r=+0.06)$ the rate of increase can be said to be very torpid and the relationship between level of crime occurrence and year was very low and direct.

$$
y=40.179+0.9048 x
$$

The model implies that a unit increase in year would bring about 0.9048 unit increase in the case of unlawful possession of contraband and mood-altering substance in Oke-Ogun region

Table 10: Predicted Trend Values for the Crime of Unlawful Possession

\begin{tabular}{llll}
\hline Year & Empirical values & $\mathbf{T n}=\boldsymbol{\alpha}(\varnothing)+(\mathbf{1}-\boldsymbol{\alpha})(\boldsymbol{\beta})$ & $\mathbf{Y}=\mathbf{a}+\mathbf{b x}$ \\
\hline $\mathbf{2 0 0 5}$ & 41 & 41.00 & 41.08 \\
$\mathbf{2 0 0 6}$ & 14 & 32.90 & 41.99 \\
$\mathbf{2 0 0 7}$ & 13 & 26.93 & 42.89 \\
$\mathbf{2 0 0 8}$ & 82 & 43.45 & 43.79 \\
$\mathbf{2 0 0 9}$ & 81 & 54.72 & 44.70 \\
$\mathbf{2 0 1 0}$ & 81 & 62.60 & 45.61 \\
$\mathbf{2 0 1 1}$ & 32 & 53.42 & 46.51 \\
$\mathbf{2 0 1 2}$ & 10 & 40.39 & 47.42 \\
\hline
\end{tabular}

Source: Field Research, 2014

\section{Summary of Predictions}

Among the nine types of crime against property, only three crime types were increasing, albeit at a slow and dilatory pace which was almost imperceptible. Two of the increasing crime types were twin crime. The twin crimes were burglary and house breaking (Table 13). The term 'burglary' is an illegally forceful entry into building in the night while house breaking is an illegally forceful entry into building during the day. 
LAUTECH Journal of Civil and Environmental Studies

Volume 7, Issue 2; September 2021

Table 11: Summary of Predictions for Typologies of Property Crime

\begin{tabular}{llll}
\hline \multicolumn{3}{l}{ CRIME AGAINST PROPERTY } & \\
\hline S/N & CRIME TYPE & TREND & TREND RATE \\
\hline $\mathbf{1}$ & Armed Robbery & Decreasing & Very fast $(\mathrm{r}=-0.73)$ \\
$\mathbf{2}$ & Burglary & Increasing & Very slow $(\mathrm{r}=+0.03)$ \\
$\mathbf{3}$ & Theft and stealing & Decreasing & Very fast $(\mathrm{r}=-0.79)$ \\
$\mathbf{4}$ & House breaking & Increasing & Slow $(\mathrm{r}=+0.22)$ \\
$\mathbf{5}$ & Store breaking & Decreasing & Very fast $(\mathrm{r}=-0.71)$ \\
$\mathbf{6}$ & Arson & Decreasing & Slow $(\mathrm{r}=-0.40)$ \\
$\mathbf{7}$ & Forgery & Decreasing & Very fast $(\mathrm{r}=-0.90)$ \\
$\mathbf{8}$ & False pretence and Cheat & Decreasing & Very fast $(\mathrm{r}=-0.78)$ \\
$\mathbf{9}$ & Unlawful possession & Increasing & Very slow $(\mathrm{r}=+0.06)$ \\
\hline
\end{tabular}

Source: Field Research, 2014

The implication of the rising trend of these twin crimes is that there was a very high level of insecurity against pecuniary and other movable material objects kept at home. Concomitantly, the results of a time series analysis of the trend of supra-urban (regional) crime at typologically disaggregated levels in Oke-Ogun have some similarities and differences with urban crime study in Akure as carried out by Okoko (2008). Okoko used Police records from 2001 to 2006 to investigate variations in long term urban crime pattern on theft, burglary, house-breaking, store-breaking, malicious and false pretence. Virtually all these urban crimes but burglary and malicious damage showed a very high rate of increase with the effluxion of years in Akure. Also, the property crime occurrence in Oke-Ogun was at variance with what obtained by Okoko (2008). While property crime in Oke-Ogun showed a fairly fast rate of decline (Figure 2), total crime in Akure exhibited an upward trend with a fairly fast rate of increase. It is evident here that regional environment is distinct from urban environment in ways that affect community policing.

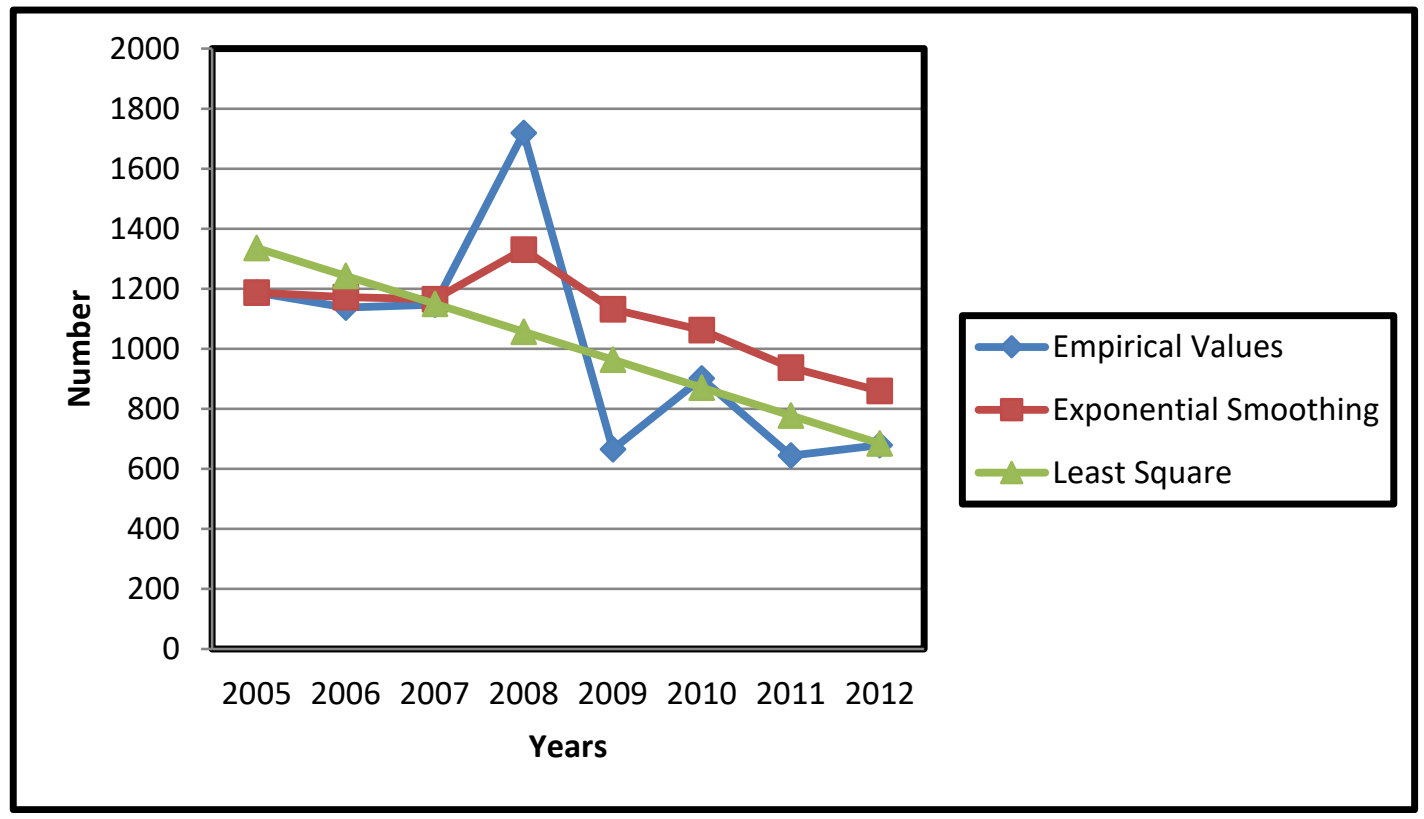

Figure 2: Geo-infographic Trend lines of Total Crime against Property

In general, the property crime occurrence in Oke-Ogun is decreasing at a rapid rate (figure 2) with regression coefficient of $(b=-93.04)$. However, it could be predicted from the model generated for crime against property that it would take Oke-Ogun area about (nine) 9 years from year 2012 to mitigate the incidence of crime against property into stymied level using least squares model $(\mathrm{y}=$ 1428.8 - 93.036x) as given in equation (1). Besides, it was understood from police officers on the behaviours of criminals in response to a specific set of conditions that some criminals might prefer quiet areas and other might prefer busy areas for their nefarious activities. If we are to transfer the 
different criminal behaviours on a chart, problem solving for total crime control in a given environment could be impossible due to complications.

\section{Conclusion and Recommendations}

The coefficient of determination $\left(r^{2}\right)$ in the case of property crime is 0.3969 . However, the study concluded that $39.69 \%$ of variations in the level of property crime were influenced by changes in year and $60.31 \%$ was explained by other factors. According to the literature review of most area studies of crime based on the routine activity theory and basic systemic model of crime, the crime composition of an area would be a result of the area's ability to develop mechanism of formal and informal control. Therefore, these other factors that bring high crime concentration in Oke-Ogun may be directly related to the inability of households to exercise suitable guardianship, and the reality of the finiteness and limitations of government resources that could be put at the disposal of effective neighbourhood policing. Upward trend in burglary (an illegally forceful entry into building in the night) and house breaking (an illegally forceful entry into building during the day) may be due to far distance of residences from police station and posts, absence of police patrol in new settlements that have scattered newly built houses dotted their landscapes and absence of street light to illuminate the area

For a policy-oriented remark, it is therefore suggested at this time that a concertedly intensified effort and determination must be ensured by the law enforcement officers that crimes are stymied. Efforts should be strategically intensified by the law enforcement officers to ensure that criminals are prevented from gaining forceful entry into residential houses during the day after the people have left home for their daily activities especially in the sub-urban areas that are far from town/village centres and security posts. The same effort should be equally put to check burglary at night coupled with the provision of street light by government to illuminate the ghost zones in the night. The rising trend of unlawful possession in Oke-ogun is portentous of palpable insecurity and a high rate insensate porosity of border areas in Oke-Ogun. Pure border law enforcement agents that are highly trained should man border to check trans-border activities because most of these activities are enormously costly to both the victims and society.

\section{References}

Adeboyejo, A.T and Abodunrin F.O. (2007). Spatio-temporal variation in urban crime in Ogbomoso. Global Journal of Environmental Sciences. 6(1), 21-26

Adejumobi, C.A. Oni, N.O. \& Ige, J.O. (2009) Crime occurrence and community policing in Southwestern Nigeria. Journal of Social Policy and Society. 4(1), 112-119

Adigun, F.O. (2012). Spatio-temporal analysis of urban crime in selected Nigerian Cities. PhD Thesis, Department of Urban and Regional Planning, Ladoke Akintola University of Technology, Ogbomoso, Nigeria

Ahmed, Y.A. (2010). Trend and pattern of urban crime in South-western Nigeria. Ph.D. Thesis, University of Ilorin. Nigeria.

Aust, R. And Simmons, J. (2002). Rural crime: England and Wales. Home Office Statistical Bulletin 01/02. London: Home Office

Jones, B. (2003). Doing problem-solving across borders in low-crime areas: The Fens experience. In K. Bullock \& N. Tilley (Eds.) Crime reduction and problem-oriented policing. Cullompton: Willan.

Mawby, R.I. (2006) Crime, Place and explaining rural hotspots, paper presented at the crime in rural communities' conference, rural crime centre, University of New England, Armidable, New South Wales, online

Obudho, R.A. and Owuor, S.O. (1994) Urbanization and crime in Kenya. In Albert, I.O.,Adisa, J., Agboola, T. and Hearault, G. (Eds) Urban management and urban violence in Africa. Ibadan: IFRA

Odekunle, F. (1982) Crime and social deviance, in Akeredolu, A. (Ed.) Social development in Nigeria; Ibadan: University Press Ltd, 
Okafor S.I (2004) Regional development planning in Agboola, T. (Ed.) Readings in Urban and Regional Planning. Macmillan Nigeria Publishers Limited, Yaba, Lagos.

Okoko, E (2000) Quantitative technique in urban analysis, Ibadan: Krafts Book Limited.

Okoko E (2008) A time-series analysis of the trend of urban violence in Akure, Nigeria. Journal of Nigerian Institute of Town Planners. 21(1) 166-183

Omisakin, I.S. (1998) Crime trends and prevention strategy in Nigeria. A study of Old Oyo State: NISER Monograph pp1-7.

Omuta G.E.D and Onokerhoraye, A.C. (1986) Regional development and planning, University of Benin Press. 